\title{
Kajian Yuridis Pasal 362 Kitab Undang-Undang Hukum Pidana dan Pasal 30 Undang-Undang Nomor 11 tahun 2008 tentang Informasi Dan Transaksi Elektronik Terhadap Pencurian Internet Wifi
}

\author{
Junaidi \\ Fakultas Hukum Universitas Sjahkyakirti \\ Jl. Sultan Muh. Mansyur Kebon Gede 32 Ilir, Kota Palembang \\ Correspondence email: junaidievy@yahoo.com
}

\begin{abstract}
Abstrak. Penggunaan internet wifi milik pribadi terutama di rumah telah menjadi hal yang biasa, internet wifi yang digunakan tanpa izin dari pemiliknya apalagi tanpa sepengetahuannya, jika hal tersebut yang terjadi akan mengakibatkan si pemilik mengalami kerugian. Internet wifi di rumah yang seharusnya digunakan oleh keluarga tetapi ikut dinikmati oleh orang lain tanpa izin dan sepengetahuan dari pemilik, pemilik yang membayar tetapi orang lain menggunakan. Tindak pidana pencurian diatur dalam Pasal 362 Kitab Undang-Undang Hukum Pidana, sedangkan dalam Pasal 30 Undang-Undang Nomor 11 tahun 2008 tentang Informasi dan Transaksi Elektronik lebih kepada akses tidak sah (illegal access). Penerapan hukum pidana dalam tindak pidana pencurian internet wifi, sebagaimana diatur dalam : a) Pasal 362 KUHP, internet wifi dapat ditafsirkan secara ekstensif sebagai salah satu bentuk "barang" yang merupakan unsur Pasal 362 KUHP, hal ini dapat disamakan dengan "listrik" dan "gas" meskipun tidak memiliki wujud, tidak terlihat dan dirasakan, tetapi mempunyai nilai ekonomis untuk dapat dikatakan sebagai "barang" karena untuk dapat menggunakan atau menikmati layanan internet wifi pengguna harus membeli paket internet wifi terlebih dahulu; b) Pasal 30 ayat (1), (2), dan (3) Undang-Undang Nomor 11 tahun 2008 tentang Informasi dan Transaksi Elektronik dapat dikenakan pada pelaku pencurian internet wifi karena berkaitan dengan akses tidak sah (illegal access). Perbuatan pencurian kuota internet dengan menggunakan software atau aplikasi computer untuk membobol jaringan internet guna memperoleh username dan password internet wifi agar mendapatkan akses menggunakan internet wifi. Dalam penyelesaian tindak pidana, pembuktian merupakan hal yang essensial, dikarenakan dalam penyelesaian perkara pidana yang dicari merupakan kebenaran materil.
\end{abstract}

Kata Kunci: Kajian Yuridis Pasal 362 KUHP; Pasal 30 Undang-Undang ITE; Pencurian Internet Wifi

Abstract. The use of private wifi internet, especially at home, has become commonplace, wifi internet is used without permission from the owner, especially without his knowledge, if this happens it will result in the owner experiencing losses. Home wifi internet that should be used by the family but is also enjoyed by other people without the permission and knowledge of the owner, the owner who pays but other people use it. The crime of theft is regulated in Article 362 of the Criminal Code, while Article $3 o$ of Law Number 11 of 2008 concerning Electronic Information and Transactions is more about illegal access. The application of criminal law ini the crime of theft of internet wifi, as regulated in : a) Article362 of the Criminal Code, internet wifi can be interpreted extensively as one form of "goods" which in an element of Article 362 of the Criminal Code, this can be equated with "electricity" and "gas" although it does not have a from, is not visible and felt, but has an economic value to be said as "goods" because to be able to use or enjoy wifi internet service users must purchase a wifi internet package first; b) Article 30 paragraph (1), (2) dan (3) Law Number 11 of 2008 concerning Electronic Information and Transaction may be imposed on perpetrators of wifi internet theft because it is related to illegal access. The act of stealing internet quota by using software or computer applications to break into the internet network to obtain a wifi internet username and password in order to gain access using wifi internet. In the settlement of a criminal act, proof is essential, because in the settlement of a criminal case what is sought is a material truth.

Keywords: Juridical Study Article 362 Book of Criminal Law; Article 30 the ITE Law; Internet Wifi Theft

\section{PENDAHULUAN}

Perkembangan teknologi komputer dan telekomunikasi banyak menghasilkan sistem-sistem jaringan komputer (computer network) yang mendunia. Pemanfaatan aplikasi penggunaan jaringan komputer tidak hanya digunakan di lingkungan penelitian, universitas dan laboratorium yang penggunaan untuk keperluan ilmiah/riset, jaringan komputer telah digunakan juga di lingkungan perbankan, perusahaan, instansi pemerintah, militer/Hankam, hukum dan peradilan dan individu/perorangan. Setiap lini kehidupan dalam penggunaannya telah memanfaatkan kecanggihan sistem komputer ${ }^{1}$.

${ }^{1}$ Al Wisnubroto, Kebijakan Hukum Pidana dalam Penanggulangan Penyalahgunaan Komputer, (Yogyakarta: Penerbit Universitas Atma Jaya, 1999), hlm. 1 
Hal ini, menunjukkan semakin meningkatkan kehidupan modern tidak lepas dari kecanggihan sistem komputer. Oleh karena itu, teknologi sistem komputer merupakan jalan menuju keberhasilan dalam pembangunan. Penggunaan jaringan komputer telah membantu dan menunjang pembangunan nasional ${ }^{2}$.

Perkembangan teknologi komputer yang sangat pesat, tidak luput dari implikasi penggunaannya yang menimbulkan efek negatif berupa penyalahgunaannya. Kehadiran jaring komputer tanpa disadari adalah proses dari suatu pembangunan yang merupakan suatu terobosan baru dalam mengubah setiap sendi-sendi kehidupan manusia. Komputer telah mampu mengubah kehidupan manusia menjadi lebih modern, hal ini juga dibarengi dengan kemajuan informasi teknologi $(\mathrm{TI})^{3}$, yang merupakan titik sentral dalam banyak kegiatan manusia tidak terkecuali di bidang hukum ${ }^{4}$.

Internet merupakan jaringan komputer yang terdiri dari berbagai macam ukuran dan jenis jaringan komputer di seluruh dunia. Jaringan-jaringan komputer ini saling berhubungan dan berkomunikasi satu sama lain melalui bantuan telepon dan satelit, yang digunakan untuk keperluan pemerintahan, pendidikan, perdagangan, ilmu pengetahuan dan perorangan. Pengertian internet (interconnection networking) sendiri adalah jaringan komunikasi global yang terbuka dan menghubungkan jutaan bahkan milyaran jaringan komputer dengan berbagai tipe dan jenis, dengan menggunakan tipe komunikasi seperti telepon, satelit dan lain sebagainya. Secara sederhana, Internet adalah kumpulan dari jutaan komputer di seluruh dunia yang terkoneksi antara yang satu dengan yang lain. Media koneksi yang digunakan bisa melalui sambungan telpon, serat optik (fiber optic), kabel koaksial (coaxial cable), satelit atau dengan koneksi wireless 5 .

Saat ini internet tidak saja digunakan sebagai komunikasi atau mencari informasi, akan tetapi telah digunakan untuk transaksi yang menghasilkan uang. Tarif akses internetpun telah mengalami penurunan sangat pesat dikarenakan telah banyak yang menggunakannya, tidak hanya di perkotaan, kini telah masuk kepedesaan, semua orang telah menggunakan akses internet ${ }^{6}$.

Kemajuan teknologi komputer juga telah banyak disalahgunakan, misalnya adanya orang yang menggunakan akses internet wifi milik orang lain tanpa izin atau sepengetahuan pemiliknya. Penggunaan internet wifi milik pribadi terutama di rumah telah menjadi hal yang biasa, internet wifi yang digunakan tanpa izin dari pemiliknya apalagi tanpa sepengetahuannya, jika hal tersebut yang terjadi akan mengakibatkan si pemilik mengalami kerugian. Internet wifi di rumah yang seharusnya digunakan oleh keluarga tetapi ikut dinikmati oleh orang lain tanpa izin dan sepengetahuan dari pemilik, pemilik yang membayar tetapi orang lain menggunakan.

Permasalahanya si pengguna tidak mengetahui kuota internet wifinya dicuri, karena sulit untuk mengetahui telah terjadinya pencurian. Peristiwa terjadinya memiliki kesamaan dengan pencurian biasa yang mengakibatkan korban dirugikan secara materiil, kerugian yang dialami korban berupa pembelian kuota internet wifi yang digunakan oknum tersebut secara gratis tanpa membayar.

Tindak pidana pencurian diatur dalam Pasal 362 Kitab Undang-Undang Hukum Pidana (KUHP), yang menyatakan bahwa:

Barang siapa mengambil barang sesuatu, yang seluruhnya atausebagian kepunyaan orang lain, dengan maksud untuk dimiliki secaramelawan hukum, diancam karena pencurian, dengan pidana penjarapaling lama lima tahun atau pidana denda paling banyak sembilan ratusrupiah.

Dalam Undang-Undang Nomor 11 Tahun 2008 tentang Informasi dan Transaksi Elektronik sebagaimana telah diubah dengan Undang-Undang Nomor 19 tahun 2016, tidak ada pasal yang mengatur larangan perbuatan mencuri internet wifi dan dalam tidak mengatur secara jelas mengenai pencurian kuota internet wifi. Pasal 30 ayat (1), (2), dan (3) Undang-Undang Nomor 11 tahun 2008 tentang Informasi dan Transaksi Elektronik sebagaimana diubah dengan Undang-Undang Nomor 19 tahun 2016 yang mungkin bisa dikaitkan dengan kasus pencurian internet wifi, yang menyatakan :

(1) Setiap Orang dengan sengaja dan tanpa hak atau melawan hukum mengakses Komputer dan/atau Sistem Elektronik milik Orang lain dengan cara apa pun.

(2) Setiap Orang dengan sengaja dan tanpa hak atau melawan hukum mengakses Komputer dan/atau Sistem Elektronik dengan cara apa pun dengan tujuan untuk memperoleh Informasi Elektronik dan/atau Dokumen Elektronik.

(3) Setiap Orang dengan sengaja dan tanpa hak atau melawan hukum mengakses Komputer dan/atau Sistem Elektronik dengan cara apa pun dengan melanggar, menerobos, melampaui, atau menjebol sistem pengamanan.

\footnotetext{
${ }^{2}$ Ibid, hlm. 2

${ }^{3}$ BPHN, Penelitian tentang Perlindungan Hukum dan Digital, (Jakarta : BPHN, 2007), hlm. 1

${ }^{4}$ Andi Hamzah dan Boedi D Marsita, Aspek-aspek Pidana di Bidang Komputer, (Jakarta : Sinar Grafika, 2007), hlm. 5

${ }^{5}$ http://itjambi.com/apa-itu-internet/, diakses pada tanggal 12 Desember 2019, pukul 13.30 WIB.

${ }^{6} \mathrm{http} / / /$ belajar-komputer-mu.com/pengertian-internet/, diakses pada tanggal 12 Desember 2019, pukul 14.30 WIB.
} 


\section{METODE}

\section{Jenis Penelitian}

Jenis penelitian yang penulis terapkan adalah penelitian yuridis normative, yakni penelitian yang difokuskan untuk mengkaji penerapan kaidah-kaidah atau norma-norma dalam hukum positif ${ }^{7}$. Penelitian ini bertujuan memberikan gambaran mengenai implementasi Undang-Undang Informasi dan Transaksi Elektronik dan pembuktian dalam pencurian kuota data internet wifi.

\section{Jenis Pendekatan}

Jenis pendekatan yang digunakan merupakan pendekatan perundang-undangan, pendekatan undang-undang (statute approach) dengan menggunakan telaah undang-undang dan regulasi yang berhubungan dengan isu hukum yang ditangani ${ }^{8}$.

\section{HASIL DAN PEMBAHASAN}

Kajian Yuridis Pasal 362 Kitab Undang-Undang Hukum Pidana dan Pasal 30 Undang-Undang Nomor 11 tahun 2008 tentang Informasi dan Transaksi Elektronik terhadap Penegakan Pencurian Kuota Internet Wifi

Perbuatan pencurian kuota internet wifi, tidak dapat dikatakan suatu tindakan pidana jika belum ada aturan yang mengatur hal tersebut secara tertulis, sebagaimana diatur Pasal 1 ayat (1) Kitab Undang-Undang Hukum Pidana "Nullum delictum nulla poena sine praevia lege poenali" atau dalam istilah lain dapat dikenal, "tiada pidana tanpa kesalahan". Tindak pidana pencurian diatur dalam Pasal 362 Kitab Undang-Undang Hukum Pidana (KUHP) tentang pencurian benda, sedangkan Pasal 30 ayat (1), (2), dan (3) Undang-Undang Nomor 11 tahun 2008 tentang Informasi dan Transaksi Elektronik sebagaimana diubah dengan Undang-Undang Nomor 19 tahun 2016 terdapat pengaturan mengenai akses ke komputer dan/atau sistem elektronik milik orang lain dengan sengaja dan tanpa hak atau melawan hukum.

Ketentuan Pasal 362 Kitab Undang-Undang Hukum Pidana, menyatakan bahwa:

Barang siapa mengambil barang sesuatu, yang seluruhnya atau sebagian kepunyaan orang lain dengan maksud untuk dimiliki secara melawan hukum, diancam karena pencurian, dengan pidana penjara paling lama lima tahun atau denda paling banyak enam puluh rupiah.

Unsur dari Pasal 362 Kitab Undang-Undang Hukum Pidana (KUHP), sebagai berikut:

1. Perbuatan "mengambil";

2. Mengambil sesuatu berupa "barang";

3. Barang yang diambil milik orang baik "seluruh atau Sebagian"; dan

4. Mengambil barang tersebut "untuk memilikinya dengan melawan hukum".

Dari unsur Pasal 362 Kitab Undang-Undang Hukum Pidana (KUHP) merumuskan tindak pidana pencurian sebagai suatu tindakan yang dilakukan seseorang mengambil barang orang lain dengan melawan hukum untuk menguasai barang itu. Internet merupakan suatu benda yang tidak dapat dilihat, berbentuk dan dirasakan, yang dapat dilihat dan didengar adalah teks, video dan suara yang berupa data internet yang telah berubah. Dari sinilah timbul persoalan apakah internet wifi dapat termasuk sebagai benda.

Menurut Moeljatno mengemukakan bahwa listrik dapat dikatakan sebagai benda dikarenakan adanya tafisr ekstensif dari Putusan HR di Belanda tahun 1921 pengertian goed (benda, barang) yang terdapat pada Pasal 362 KUHP meliputi juga daya listrik. Pengertian goed pada saat dibentuk hanya berupa benda berwujud ${ }^{10}$. Oleh karena itu listrik termasuk benda, sehingga dapat dijadikan suatu objek pencurian. Listrik di dalam hukum pidana merupakan suatu analogi dari benda.

Internet wifi merupakan barang yang bernilai ekonomis. Dikatakan demikian karena untuk dapat menggunakan atau menikmatinya pengguna diharuskan membeli paket internet wifi di mana layanan tersebut disediakan oleh perusahaan penyedia jaringan internet wifi atau disebut juga provider. Internet wifi tersebut juga memiliki batasan atau biasa disebut dengan kuota sehingga dalam penggunaannya internet wifi tersebut terbatas dan apabila kuota internet wifi tersebut habis pengguna diharuskan membeli paket internet wifi yang baru. Semakin banyak jumlah kuota paket internet wifi yang akan digunakan maka harga yang dikenakan semakin mahal ${ }^{11}$.

\footnotetext{
${ }^{7}$ Jhoni Ibrahim, Teori \& Metode Penelitian Hukum Normatif, (Malang : Bayu Media, 2005), hlm. 295

${ }^{8}$ Peter Mahmud, Penelitian Hukum, cetakan ke-4, (Jakarta : Kencana Pradana Media Grup, 2008), hlm. 93

${ }^{9}$ Widodo, Aspek Hukum Pidana Kejahatan Mayantara, (Yogyakarta : Aswaja Pressindo, 2013), hlm. 27

${ }^{10}$ Moeljatno, Asas-asas Hukum Pidana (KUHP), beserta Komentar-komentarnya Lengkap Pasal demi Pasal, (Bogor :
} Politeia, 1996), hlm. 29

${ }^{11}$ https://jalantikus.com/tips/alasan-kenapa-ada-kuota/, diakses pada tanggal 23 Januari 2020. 
Internet wifi yang tidak dapat dilihat dan disentuh dalam hal ini diambil melalui adaptor wireless atau antena karena internet wifi berbentuk pancaran gelombang radio atau jaringan wireless (jaringan tanpa kabel). Cara kerja internet wifi yakni data yang dikirimkan oleh pengguna di udara berupa gelombang radio. Data atau dokumen yang dikirimkan tersebut dapat diterima jaringan komputer maka diperlukan suatu wireless sehingga dapat terhubung. Gelombang radio yang berupa sinyal ini kemudian dikirim menuju router. Router berfungsi sebagai pemancar internet wifi sekaligus sebagai jembatan antara data yang dikirim dan diterima. Data tersebut melewati router yang bekerja dengan dua arah kemudian diterima oleh adaptor komputer. Jadi apabila sistem keamanan di dalam router berhasil ditembus pencuri maka jaringan internet wifi dapat ditangkap oleh antena atau adaptor yang berada dalam laptop, komputer, smartphone, dan alat elektronik lainnya setelah itu internet wifi tersebut dapat digunakan oleh pelaku pencurian $^{12}$.

Dari yang dikemukakan di atas maka dapat disimpulkan bahwa unsur "mengambil" dalam kasus pencurian internet wifi terpenuhi unsurnya.

Dengan demikian, dikaitkan dengan Undang-Undang Nomor 11 tahun 2008 tentang Informasi dan Transaksi Elektronik, titik tekannya bukan pada pencuriannya tetapi bagian akses yang tidak sah (illegal access). Pasal 1 angka 5 Undang-Undang Nomor 11 tahun 2008 tentang Informasi dan Transaksi Elektronik dijelaskan sistem elektronik merupakan suatu perangkat yang mempunyai fungsi untuk mengumpulkan, mengolah, menyimpan, menganalisis, menampilkan, mengumumkan dan mengirimkan berbagai informasi elektronik.

Dari definisi tersebut, maka internet wifi termasuk dalam sistem elektronik karena fungsinya adalah mengirimkan dan/atau menyebarkan serta menerima informasi elektronik dari suatu perangkat elektronik ke perangkat elektronik yang lain yang saling berhubungan. Beberapa tindak pidana yang terkait dengan akses secara tidak sah terhadap komputer dan/atau Sistem Elektronik milik orang lain diatur dalam Pasal 30 Undang-Undang Nomor 11 tahun 2008 tentang Informasi dan Transaksi Elektronik, yang menyatakan :

(1) Setiap orang dengan sengaja dan tanpa hak atau melawan hukum mengakses Komputer dan/atau Sistem Elektronik milik Orang lain dengan cara apapun.

(2) Setiap orang dengan sengaja dan tanpa hak atau melawan hukum mangakses Komputer dan/atau Sistem elektronik dengan cara apapun dengan tujuan untuk memperoleh Informasi Elektronik dan/atau Dokumen Elektronik.

(3) Setiap orang dengan sengaja dan tanpa hak atau melawan hukum mengakses Komputer dan/atau Sistem Elektronik dengan cara apapun dengan melanggar, menerobos, melampaui, atau menjebol sistem pengamanan.

Unsur-unsur dari Pasal 30 ayat (3) Undang-Undang Nomor 11 tahun 2008 tentang Informasi dan Transaksi Elektronik, sebagai berikut:

1. Dengan sengaja dan tanpa hak atau melawan hukum;

2. Mengakses komputer dan/atau sistem elektronik;

3. Dengan cara apapun dengan melanggar, menerobos, melampaui, atau menjebol suatu sistem pengamanan.

Dari unsur di atas Pasal 30 ayat (3) Undang-Undang Nomor 11 tahun 2008 tentang Informasi dan Transaksi Elektronik merumuskan bahwa perbuatan setiap orang yang dengan sengaja dan tanpa hak atau melawan hukum mengakses komputer dan/atau sistem elektronik dengan cara apapun dengan dengan melanggar, menerobos, melampaui, atau menjebol suatu sistem pengamanan tersebut dilarang dan diancam sanksi pidana. Dalam perbuatan pencurian internet wifi pelaku terlebih dulu menjebol sistem keamanan yang ada pada router yang tersambung pada alat elektronik untuk dapat mengakses internet wifi milik korbannya. Internet wifi termasuk dalam sistem elektronik. Pelaku pencurian melakukan akses pada internet wifi dengan sengaja dan tanpa hak atau melawan hukum atau dapat juga disebut dengan akses tidak sah (Illegal access) $)^{13}$.

Dalam hukum pidana jika dalam suatu perbuatan masuk dalam lebih dari satu aturan hukum pidana maka masuk dalam delik concursus idealis. Concursus idealis atau endaadse samenloop atau perbarengan peraturan yang diatur dalam Pasal 63 ayat (1) Kitab Undang-Undang Hukum Pidana (KUHP) yang menyatakan:

Jika suatu perbuatan masuk dalam lebih dari satu aturan pidana, maka yang dikenakan hanya salah satu diantara aturan-aturan itu; jika berbeda-beda, yang dikenakan yang memuat ancaman pidana pokok yang paling berat.

Adapun kriteria dari concursus idealis adalah berbarengan dan persamaan sifat dari perbuatan yang dilakukan ${ }^{14}$.

Dengan demikian pencurian internet wifi memenuhi Pasal 30 ayat (3) Undang-Undang Nomor 11 tahun 2008 tentang Informasi dan Transaksi Elektronik karena pelaku melakukan akses tidak sah (illegal access) pada sistem

12 Agus Rahardjo, Cybercrime Pemahaman dan Upaya Pencegahan Kejahatan Berteknologi, (Bandung : Citra Aditya Bakti, 2002), hlm. 83

${ }^{13}$ Widodo, Memerangi Cybercrime : Karakteristik Motivasi dan Strategi Penanggulanggan dalam Perspektif Kriminologi, (Yogyakarta : Aswaja Pressindo, 2013), hlm. 67-69

${ }^{14}$ Eddy O.S Hiariej, Prinsip-Prinsip Hukum Pidana, (Yogyakarta : Cahaya Atma Pustaka, 2014), hlm. 338. 
elektronik router dengan menjebol sistem keamanannya untuk dapat menggunakan internet wifi. Dengan terpenuhinya unsur-unsur dalam Pasal 30 ayat (3) Undang-Undang Nomor 11 tahun 2008 tentang Informasi dan Transaksi Elektronik maka secara otomatis juga memenuhi unsur-unsur dalam Pasal 30 ayat (1) dan (2) Undang-Undang Nomor 11 tahun 2008 tentang Informasi dan Transaksi Elektronik. Berkaitan dengan analisis tersebut maka pencurian internet wifi memenuhi Pasal 30 ayat (1), (2), dan (3) Undang-Undang Nomor 11 tahun 2008 tentang Informasi dan Transaksi Elektronik.

Dalam Pasal 30 Undang-Undang Nomor 11 tahun 2008 tentang Informasi dan Transaksi Elektronik ada tiga ayat yang semuanya memiliki kesamaan unsurnya yakni dalam unsur akses tidak sah yang dilakukan pada komputer dan/atau sistem elektronik yang dilakukan cara tertentu. Dengan pertimbangan tersebut sesuai dengan delik concursus idealis maka dikenakan salah satu aturan pidana dengan ancaman paling berat. Pasal 46 Undang-Undang Nomor 11 tahun 2008 tentang Informasi dan Transaksi Elektronik yang mengatur ancaman pidana Pasal 30 Undang-Undang Nomor 11 tahun 2008 tentang Informasi dan Transaksi Elektronik menyebutkan bahwa Pasal 30 ayat (3) yang mempunyai ancaman paling berat.

Dengan demikian dapat ditarik kesimpulan bahwa dalam perbuatan pencurian wifi apabila terbukti pelaku dikenakan Pasal 30 ayat (3) Undang-Undang Nomor 11 tahun 2008 tentang Informasi dan Transaksi Elektronik.

\section{Pembuktian Hukum Pasal 362 Kitab Undang-Undang Hukum Pidana dan Pasal 30 Undang-Undang Nomor 11 tahun 2008 tentang Informasi dan Transaksi Elektronik dalam Kasus Pencurian Kuota Internet Wifi}

Cybercrime atau computer-related crime adalah aktivitas manusia di dunia mayantara (maya) yang menjadikan komputer sebagai sasaran kejahatan (misalnya akses ilegal, perusakan situs, intersepsi ilegal) dan aktivitas manusia yang menggunakan komputer sebagai sasaran kejahatan (misalnya pemalsuan kartu kredit, pornografi via internet) ${ }^{15}$.

R.Wirjono Prodjodikoro yang mengemukakan suatu kebenaran mengenai keadaan-keadaan tertentu, makin lama keadaan tersebut maka akan makin sulit bagi hakim dalam menyatakan suatu kebenaran. Bahwa apa yang diyakini oleh hakim tentang suatu keadaan tertentu harus bersesuaian dengan kebenaran. Hukum acara pidana merupakan suatu cara yang berusaha mendekati keadaan-keadaan tertentu tersebut agar bersesuaian dengan kebenaran. Untuk membuktikan keadaan yang sudah lampau itu hakim memerlukan suatu alat yang dapat menggambarkan keadaan tersebut ${ }^{16}$.

Dalam menyelesaikan suatu perkara pidana, pembuktian merupakan hal yang sangat penting dan krusial. Pembuktian dapat memberikan landasan dan argumen yang kuat bagi Penuntut Umum dalam mengajukan tuntutan. Pembuktian merupakan sesuatu yang bersifat objektif dan memberikan informasi kepada hakim untuk menentukan sikap dan kesimpulan dalam menyelesaikan perkara pidana yang disidangkan. Pembuktian dalam perkara pidana merupakan sesuatu yang sangat penting dikarenakan dalam pidana yang dicari adalah kebenaran materil ${ }^{17}$.

Pembuktian pada perkara pidana dimulai dalam tahap pendahuluan yakni pada saat penyelidikan dan penyidikan. Pada tahap ini pembuktian lebih rumit dibandingkan hukum acara lainnya. Penyelesaian perkara pidana meliputi beberapa tahap diantaranya penyelidikan dan penyidikan pada kepolisian, penuntutan di kejaksaan, pemeriksaan perkara di pengadilan negeri, upaya hukum di pengadilan tinggi dan mahkamah agung, eksekusi oleh eksekutor jaksa penuntut umum. Pembuktian dalam perkara pidana melibatkan instansi kepolisian, kejaksaan dan pengadilan ${ }^{18}$.

Berdasarkan Pasal 5 ayat (1), ayat (2) dan Pasal 44 huruf b Undang-Undang Nomor 19 tahun 2016 tentang Perubahan Atas Undang-Undang Nomor 11 tahun 2008 tentang Informasi dan Transaksi Elektronik. Informasi elektronik dan/atau dokumen elektronik dan/atau hasil cetakannya merupakan perluasan dari alat bukti hukum yang sah sesuai dengan hukum acara yang berlaku di Indonesia.

Masuknya informasi dan dokumen elektronik sebagai alat bukti elektronik dikarenakan informasi dan dokumen elektronik bersifat mengikat dan sebagai alat bukti yang sah dalam memberikan kepastian hukum, terutama dalam pembuktian yang terkait sistem elektronik ${ }^{19}$.

Pada prakteknya penegak hukum (hakim dan jaksa) terbagi 2 (dua) pendapat mengenai alat bukti elektronik. Ada yang memposisikan informasi dan/atau dokumen elektronik sebagai alat bukti keenam, ada yang menjadikan alat bukti elektronik sebagai perluasan dari alat bukti di Pasal 184 ayat (1) Kitab Undang-Undang Hukum Acara Pidana (KUHAP). Untuk menjelaskan alat bukti elektronik diperlukan seorang ahli digital forensic, bahwa seorang ahli digital forensic akan menentukan keabsahan suatu alat bukti elektronik di persidangan. Berangkat dari prinsip bahwa

\footnotetext{
${ }^{15}$ Widodo, Aspek Hukum Pidana Kejahatan Mayantara, (Yogyakarta : Aswaja Pressindo, 2013), hlm. 4.

${ }^{16}$ R. Wirjono Projodikoro, Hukum Acara Pidana di Indonesia, (Bandung : Sumur, 1974), hlm. 89

${ }^{17}$ Eddy O.S Hiariej, Op.cit, hlm. 96

18 Ibid

${ }^{19}$ Lihat Penjelasan Pasal 5 ayat (1) Undang-Undang Nomor 19 tahun 2016 tentang Perubahan Kedua atas Undang-Undang Nomor 11 tahun 2011 tentang Informasi dan Transaksi Elektronik
} 
every evidence can talk, yang dapat membuat alat bukti elektronik "berbicara" adalah seorang ahli digital forensic. Penjelasan ahli tersebut nantinya akan dilakukan dengan cara merekonstruksi alat bukti elektronik, sehingga membuat terang jalannya persidangan ${ }^{20}$.

\section{SIMPULAN}

1. Kajian yuridis hukum pidana dalam tindak pidana pencurian internet wifi, sebagaimana diatur dalam :

a. Pasal 362 Kitab Undang-Undang Hukum Pidana (KUHP), internet wifi dapat ditafsirkan secara ekstensif sebagai salah satu bentuk "barang" yang merupakan unsur Pasal 362 Kitab Undang-Undang Hukum Pidana (KUHP), dapat disamakan dengan aliran "listrik" dan "gas" yang mempunyai nilai ekonomis walaupun tidak berbentuk dan tidak dapat dilihat untuk dapat dikatakan sebagai "barang" karena untuk dapat menggunakan atau menikmati layanan internet wifi pengguna harus membeli paket internet wifi terlebih dahulu. Dengan demikian Pasal 362 Kitab Undang-Undang Hukum Pidana (KUHP) dapat dikenakan pada pelaku pencurian internet wifi.

b. Pasal 30 ayat (1), (2), dan (3) Undang-Undang Nomor 11 tahun 2008 tentang Informasi dan Transaksi Elektronik, dimana para pelaku melakukan perbuatan akses tidak sah (illegal access) untuk menerobos internet wifi pada sistem elektronik dengan cara menembus keamanan untuk bisa mengetahui username dan password dalam mengakses internet wifi. Berdasarkan Pasal 30 ayat (1), (2), dan (3) Undang-Undang Nomor 11 tahun 2008 tentang Informasi dan Transaksi Elektronik dapat dikenakan pada pelaku pencurian internet wifi karena berkaitan dengan akses tidak sah (illegal access).

2. Perbuatan pencurian internet wifi dapat terjadi dikarenakan ketidaktahuan pemilik internet wifi, disebabkan para pelaku dalam melakukan aksinya menggunakan aplikasi software tertentu agar bisa menembus jaringan komputer guna mendapatkan username dan password untuk mengakses internet wifi. Dalam perkara pidana, pembuktian sangatlah esensial karena yang dicari dalam perkara pidana adalah kebenaran materil.

\section{DAFTAR PUSTAKA}

\section{Buku}

Agus Rahardjo, Cybercrime Pemahaman dan Upaya Pencegahan Kejahatan Berteknologi, Bandung: Citra Aditya Bakti, 2002.

Al Wisnubroto, Kebijakan Hukum Pidana dalam Penanggulangan Penyalahgunaan Komputer, Yogyakarta: Penerbit Universitas Atma Jaya, 1999.

Andi Hamzah dan Boedi D Marsita, Aspek-aspek Pidana di Bidang Komputer, Jakarta : Sinar Grafika, 2007.

BPHN, Penelitian tentang Perlindungan Hukum dan Digital, Jakarta: BPHN, 2007.

Eddy O.S Hiariej, Prinsip-Prinsip Hukum Pidana, Yogyakarta: Cahaya Atma Pustaka, 2014.

Jhoni Ibrahim, Teori \& Metode Penelitian Hukum Normatif, Malang: Bayu Media, 2005.

Mahrus Ali, Dasar-Dasar Hukum Pidana, Jakarta: Sinar Grafika, 2011.

Moeljatno, Asas-asas Hukum Pidana (KUHP) beserta Komentar-komentarnya Lengkap Pasal demi Pasal, Bogor: Politeia, 1996.

Peter Mahmud, Penelitian Hukum, cetakan ke-4, Jakarta: Kencana Pradana Media Grup, 2008.

R. Wirjono Prodjodikoro, Hukum Acara Pidana di Indonesia, Bandung: Sumur, 1974.

Wiryono Surachmand, Pengantar Penelitian Ilmiah, Bandung: Tarsio, 1991.

Widodo, Aspek Hukum Pidana Kejahatan Mayantara, Yogyakarta: Aswaja Pressindo, 2013. , Memerangi Cybercrime: Karakteristik Motivasi dan Strategi Penanggulanggan dalam Perspektif Kriminologi, Yogyakarta: Aswaja Pressindo, 2013.

\section{Skripsi, Tesis, Disertasi, Jurnal, Makalah}

Komisaris Besar Polisi Muhammad Nuh Al-Azhar, MSc., CHFI., CEI., ECIH dalam Pelatihan Hukumonline 2019, Memahami Cyber Law, Cyber Crime, dan Digital Forensic dalam Sistem Hukum Indonesia (Angkatan Keenam), Rabu 23 Januari 2019

\section{Internet}

http://itjambi.com/apa-itu-internet/ http://belajar-komputer-mu.com/pengertian-internet/ https://jalantikus.com/tips/alasan-kenapa-ada-kuota/

${ }^{20}$ Pendapat Komisaris Besar Polisi Muhammad Nuh Al-Azhar, MSc., CHFI., CEI., ECIH dalam Pelatihan Hukumonline 2019, Memahami Cyber Law, Cyber Crime, dan Digital Forensic dalam Sistem Hukum Indonesia (Angkatan Keenam), Rabu 23 Januari 2019 